\title{
Radio as A Tool for Society Empowerment in Sub-Saharan States
}

\author{
Yeremia Nicolaus Widjanarko \\ Universitas Airlangga
}

\begin{abstract}
ABSTRAK
Perkembangan pesat yang dialami oleh media massa telah mengubah cara masyarakat untuk memperoleh informasi. Hal ini dibuktikan melalui eksistensi dari teknologi komunikasi dan informasi, yang penggunaannya membutuhkan berbagai syarat seperti tingkat pendidikan yang mumpuni, kondisi ekonomi yang baik, serta adanya infrastruktur yang memadai. Persyaratan tersebut dapat dengan mudah dipenuhi oleh masyarakat di negara-negara maju, tetapi tidak oleh masyarakat di negara-negara sub-sahara. Alhasil, masyarakat di negara-negara subSahara lebih sering mengguna-kan radio sebagai media massa untuk memperoleh informasi. Berkaca dari fenomena tersebut, penulis melihat adanya peluang untuk menggunakan radio sebagai alat pemberdayaan masyarakat, tepatnya melalui penyebaran pengetahuan endemik. Penulis lantas menggunakan metode marginal utilitarianisme dengan pendekatan bottom-up untuk menjelaskan bagaimana pemanfaatan radio dalam pemberdayaan masyarakat dengan hasil akhir berupa metode information blending. Adapun tujuan dari pembuatan karya ini adalah untuk memberikan cara baru dalam pengembangan masyarakat, tepatnya melalui penggunaan media massa tradisional.
\end{abstract}

Kata-Kata Kunci: Afrika, Pengembangan, Pemberdayaan, Radio, Masyarakat.

The rapid development experienced by the mass media has changed the way societies access information. It could be proven by the existence of communication and information technology, which requires various conditions such as qualified educational experiences, good economic conditions, and the existence of adequate infrastructures. However, these requirements are not easy to be met by people in sub-Saharan countries. As a result, people in sub-Saharan countries use radio instead as a mass media to obtain information. Regarding this phenomenon, the author sees an opportunity to use radio as a tool for community empowerment, precisely through the spread of endemic knowledge. The author then uses the marginal utilitarianism method with a bottom-up approach explaining how radio could be used in community empowerment which resulted into information blending methods. The purpose of the paper itself is to give new insight on ways to empower society, precisely through the use of traditional mass media.

Keywords: Africa, Development, Empowerment, Radio, Society. 


\section{Introduction}

The paradigm of modernism emphasized top-down approach and is considered important by experts due to the changes or rapid development its made for people's lives (Moore and Schmitz 1995). Furthermore, the paradigm of modernism is also regarded as one of the most effective paradigms in the society development in terms of information or knowledge that can be proven by some requirements to be met by public to obtain information or knowledge, those are (1) qualified educational experience that relates to the a foreign language ability - either in form of oral or written. The society who initiates to obtain information or knowledge does not come from an English-speaking country; (2) good economic conditions, in terms of public's purchasing power to obtain devices that can be used to access online news site or other site, because these devices are often available at relatively high prices; (3) living in areas with adequate infrastructure, to ease the supporting elements in the process of obtaining information or knowledge through online news sites, such as a stable internet network that can be easily accessed by the technology devices used; and (4) well versed in technological mastery, in regard to the ability to use various technological devices to obtain information or knowledge through online news sites (Ogan et al. 2009).

The implications of the modernism in the subject of mass media, information and communication technology can be identified through some demands that must be fulfilled by the public as an effort to obtain information can be met easily by people living in developed states. Since people living in such states have qualified educational experience, relatively good economic conditions, living in areas with adequate infrastructure and fluent in technology mastery (Ogan et al. 2009). However, the fulfillment of these demands can not be done in sub-Saharan states where the majority have societal conditions contrary to the developed states such as (1) the majority of the population have never received proper education,that makes the people of Sub-Saharan states unable to understand written English; (2) relatively low economic conditions of the population, resulting in low purchasing power on modern technological devices to access online news sites and sub-Saharan states often use radio to obtain information or knowledge because of affordable radio prices; (3) the majority of the population living in rural areas without adequate infrastructure so often do not have internet network; and (4) low ability in technology mastery so that 
they can not use technology tools properly and correctly (Ilboudo and del Castello 2003). Therefore, moderism in terms of top-down approach is not applicable in sub-Saharan society since it's force the society that cannot be fullfiled by the paradigm of modernism. It will not create development, but marginalization of sub-Saharan society instead (Milan 2009). Based on these conditions, there should be another paradigm with a bottom-up approach in order to develop sub-Saharan society through the utilization of all elements contained in sub-Saharan states with the aim to create society development in the matter of mass media as well as efforts to acquire information or knowledge and avoid the emergence of the demands that the society must fulfill.

This paper is done by using marginal paradigm of utilitarianism with a bottom-up approach through the use of radio to develop subSaharan society through the dissemination of indigenous knowledge or information. This paper is supported by some empirical data about the condition African states' people in result of the blending method of information or knowledge contained on the online news sites and the needs or interests of the community are implicated through indigenous knowledge required. This paper is divided into three parts; (1) the exposure of differences radio and online mass media roles to develop sub-Saharan society; (2) the authors' arguments concerning the condition of the sub-Saharan country's society which is accompanied by empirical data comprising percentage of geographical distribution areas of people's residence, percentage of people without education, percentage of people's households own radio, percentage of people who listen to radio at least once a week and percentage of people who hear indigenous knowledge on radio; (3) blending method as a form of community development of sub-Saharan states through radio utilization in the context of spreading indigenous knowledge or information; and (5) conclusion.

\section{Mass Media Educational Function in Society Empowerment}

Mass media has several main functions that can be utilized as a tool for community development or empowerment. According to Michiels and Van Crowder (2001) the main function of mass media consists of (1) informative, which means the mass media becomes a source of acquisition of information or knowledge required by the community; (2) entertaining, which means that the mass media becomes a useful medium to display a variety of aesthetic arts and 
aims to entertain the public; and (3) educating, which means that the mass media is one of the mediums for conducting informal education to the community through the process of disseminating certain information and knowledge. The function of mass media that will be emphasized by the authors in this paper is the educating function which aims to educate the public through the dissemination of indigenous knowledge or information in people's lives. The educating function has several points that need attention, those are (1) the ability to make the community recognize the various social elements they have, this point relates to the purpose of procuring the function of educating the mass media which has a role to help people recognize what they have like their characteristics or characteristics (Parpart 1995); (2) the ability to reinforce the various social elements contained in the public order, this point relates to the habit of society which tends to be primordial with the aim of preserving a social element in society (Effendy 1992); and (3) protect the social elements that are owned by the community, this point relates to mass media efforts that can be made to make people feel that they have something important in their lives so that society has a moral responsibility to protect what they have such (Rakhmat 1998). Based on these three points, it can be assumed that the educating function possessed by the mass media pays attention to the social conditions or elements contained in a society's order and this causes differences in the application of the educating function to the developed states with the sub-saharan states's communities.

The implementation of media-educating function of mass media to sub-Saharan states has significant differences in compared with application of media-educating function of mass to the society in developed states, such as European and American society. These differences can be identified from several things such as (1) the affordability of the mass media, the majority of people in the subSaharan states, which have weak economic conditions so that they are able to reach traditional mass media such as radio better. In the contrary, most European societies have strong economic conditions, therefore they are able to operate computers or smartphones to access online mass media (Hicks, Halpin, and Hoskins 2000); (2) Indigenous knowledge or information, sub-Saharan countries community tend to have a passion for the issues of local communities or communities in their states, such as education and others. On the other hand, European societies tends to fond various global public issues, because in general what happens in their country will have an impact on other states in the world (Knight 1995); (3) oral 
culture, the majority of the people of the sub-Saharan states do not have a qualified educational experience. Therefore, it is very difficult for people in sub-Saharan states to get used to write and read. This situation created an oral culture, which is different from the culture of European society that tends to write and read (Ilboudo and del Castello 2003). Based on these three differences, it can be suspected that the people of sub-Saharan states find it easier to reach radio as a mass media to obtain information or knowledge, to have a penchant for indigenous knowledge or information that addresses local issues, and uses oral culture caused by inadequate educational experience. Thus, development empowerment in the community will be more effective by using radio that provides information or knowledge related to local issues.

\section{Arguments and Empirical Data}

The author has several arguments for factors that urge the empowerment in the community of sub-Saharan states, so that it will be more effective. It needs to get done through the use of radio, an oral mass media. Some of the arguments held by the authors are supported by data obtained from the Demographic Health Survey (DHS) who conducted research on the conditions of Anglophone sub-Saharan country communities, such as Ghana, Kenya, Lesotho, Liberia, Malawi, Namibia, Nigeria , Sierra Leone, Swaziland, Tanzania, Uganda, Zambia and Zimbabwe. The first argument is the tendency of sub-Saharan country communities to live in rural areas lacks adequate infrastructure and are not accessible to the Internet network, so that they can not access online mass media effectively. The argument is supported by the data listed below (see Table 1). The data states that sub-Saharan states have majority of residents who live in rural areas with adequate infrastructure and is not be able to afford internet network in percentage above $50 \%$.

\begin{tabular}{|c|c|c|}
\hline State or Country & Rural & Urban \\
\hline Ghana & 55 & 45 \\
\hline Kenya & 80 & 20 \\
\hline Lesothof & 74 & 26 \\
\hline Liberia & 61 & 39 \\
\hline
\end{tabular}




\begin{tabular}{ll|l} 
Malawi & 85 & 15 \\
Namibia & 60 & 40 \\
Nigeria & 67 & 33 \\
Sierra Leone & 67 & 33 \\
Swaziland & 79 & 21 \\
Tanzania & 76 & 24 \\
Uganda & 87 & 13 \\
Zambia & 65 & 35 \\
Zimbabwe & 69 & 31
\end{tabular}

5

40

33

33

21

24

13

35

31

Notes: The data are from the Demographic and Health Surveys, for society aged 15-49

The next argument is an index of education without communities in sub-Saharan states, that caused them to not be able to read and write. The argument is supported by the data below (see Table 2). The data shows that sub-Saharan states, especially the people living in rural areas, have the vast majority no qualified educational experience that can not make written and reading culture work well in sub-Saharan states. It can also be observed that Sierra Leone has the highest percentage of uneducated population among sub-Saharan states that can be seen from the percentage of rural unemployment by $93 \%$ of the rural population in Sierra Leone and $53 \%$ of the urban population in Sierra Leone.

Table 2. People without education (in percentages)

\begin{tabular}{ll|l|}
\hline State or Country & Rural & Urban \\
\hline Ghana & 54 & 23 \\
Kenya & 31 & 7 \\
Lesotho & 13 & 1 \\
Liberia & 86 & 38 \\
Malawi & 51 & 16 \\
Namibia & 22 & 4 \\
Nigeria & 65 & 22 \\
Sierra Leone & 93 & 53 \\
Swaziland & 17 & 10 \\
Tanzania & 40 & 15 \\
Uganda & 44 & 15
\end{tabular}




\begin{tabular}{l|l|l|} 
Zambia & 60 & 27 \\
Zimbabwe & 27 & 7 \\
\hline $\begin{array}{l}\text { Notes: The data are from the Demographic and Health Surveys, } \\
\text { for society aged 15-49 }\end{array}$ \\
\hline
\end{tabular}

The third argument the authors have is that sub-Saharan states are better able to reach and have radio mass media because radio is often available at affordable prices to them and it is in harmony with the economic conditions of poor sub-Saharan states. The argument is supported by the data below (see Table 3). The data shows the percentage of people in sub-Saharan states who have radios in their homes. Based on these data, $40 \%$ of people in rural areas have radio in their homes and 70\% for people living in urban areas.

Table 3. People's household whom own radio (in percentages)

\begin{tabular}{ll|l|}
\hline State or Country & Rural & Urban \\
\hline Ghana & 69 & 79 \\
Kenya & 71 & 82 \\
Lesotho & 55 & 78 \\
Liberia & 39 & 73 \\
Malawi & 59 & 79 \\
Namibia & 70 & 82 \\
Nigeria & 69 & 84 \\
Sierra Leone & 43 & 78 \\
Swaziland & 74 & 82 \\
Tanzania & 52 & 76 \\
Uganda & 58 & 75 \\
Zambia & 50 & 71 \\
Zimbabwe & 78 \\
\hline Notes: The data are from the Demographic and Health Surveys, \\
for society aged 15-49 \\
\hline
\end{tabular}

The next argument is that many sub-Saharan states listen to the radio for information or knowledge due to oral culture in the customs of sub-Saharan states and the argument is supported by the following data (see Table 4). The data shows number of people who listen to the radio at least once a week. Based on this data, many sub-Saharan people listens to radio at least once a week for rural areas at least 50\% and urban areas above $70 \%$. If further suspected, 
Namibia is the country with the highest number of radio listeners in rural areas with a percentage of $76 \%$ and Uganda with radio listeners in urban areas with a percentage of $90 \%$.

Table 4. People who listen to radio at least once a week (in percentages)

\begin{tabular}{ll|l|}
\hline State or Country & Rural & Urban \\
\hline Ghana & 72 & 81 \\
Kenya & 75 & 83 \\
Lesotho & 59 & 78 \\
Liberia & 32 & 71 \\
Malawi & 64 & 79 \\
Namibia & 76 & 85 \\
Nigeria & 46 & 69 \\
Sierra Leone & 35 & 65 \\
Swaziland & 74 & 76 \\
Tanzania & 55 & 80 \\
Uganda & 70 & 90 \\
Zambia & 50 & 71 \\
Zimbabwe & 29 & 77 \\
\hline Notes: The data are from the Demographic and Health Surveys, \\
for society aged 15-49 \\
\hline
\end{tabular}

The last argument emphasized that many sub-Saharan states listen to radio for indigenous knowledge or information, they even provide feedback that shows if sub-Saharan states needed information or knowledge about local issues in their country and the activeness of the community in the process of indigenous knowledge or information making. The argument is supported by the data below (see Table 5). The last data listed above shows the percentage of people in sub-Saharan states who listen to indigenous knowledge or information such as issues concerning the health of local communities, local politics, and other issues that represents local community or community that in sub-Saharan states, as well as sending feedback on radio-broadcast issues. In table 5, it can be assumed that rural population in the sub-Saharan states mostly has low percentage, many of which are still below 50\%, while the urban population of the sub-Saharan states has much larger percentage, many of which are already over 50\%. These data indicate that the people of sub-Saharan 
states have good level of activity in order to build an interactive and active atmosphere in terms of knowledge or information-making process in order to empower the community through the dissemination of indigenous knowledge or information.

Table 5. People who hear indigenous knowledge on radio and give feedback (in percentages)

\begin{tabular}{ll|l|}
\hline State or Country & Rural & Urban \\
\hline Ghana & 55 & 66 \\
Kenya & 66 & 78 \\
Lesotho & 18 & 25 \\
Liberia & 24 & 51 \\
Malawi & 65 & 78 \\
Namibia & 48 & 57 \\
Nigeria & 31 & 54 \\
Sierra Leone & 48 & 75 \\
Swaziland & 56 & 71 \\
Tanzania & 30 & 52 \\
Uganda & 16 & 42 \\
Zambia & 36 & 64 \\
Zimbabwe & 67 & 73 \\
\hline Notes: The data are from the Demographic and Health Surveys, \\
for society aged 15-49 \\
\hline
\end{tabular}

Some of the arguments that have been given by the author and empirical data used to support these arguments further used to state the empowerement development of communities in sub-Saharan states. It can be done through the spread of indigenous knowledge or information using mass media. Radio is in the center of the topic due to some factors underlying the community of sub-Saharan states, such as unfavorable economic conditions, uncompetent educational experience and residences that do not have adequate infrastructure and internet network. It is one of the effective methods empower development for sub-Saharan states.

\section{Radio and Online Mass Media Blending to Empower Sub-Saharan Society}

The condition of people in the sub-Saharan countries lacks of educational experience, inadequate infrastructure housing, and oral 
culture attached to the community make radio as a mass media that is most often used to obtain indigenous knowledge or information. The author assumes that the use of radio to empower the people of sub-Saharan countries through the dissemination of indigenous knowledge or information is one of the effective ways when compared to the used of mass media (Manzo 1995). However, the author also believes that information and communication technology can also be used as a source to obtain the views of the global community on issues related to the community of sub-Saharan countries. Therefore, there is a need to blend technologies between the use of radio and online mass media. It can be used to obtain sources on an issue as the author of James's (2005) emphasized, that the adoption of technological blending with the aim for creating something effectively. The author uses five variables to create this state. These variables consist of (1) state's or people's needs represented by local issues; (2) responses to local issues as a form of bottom-up approach and global mass media online views as a form of top-down approach; (3) state-sponsored or community-sponsored training, as a form of society or community empowerment, to combine views and to produce indigenous knowledge or information; (4) oral information dissemination using radios; and (5) feedbacks from people as a form of society participation in indigenous knowledge making process. These five variables have been compiled by the author so that they become a systematic method according to the chart listed below (see Figure 1).

\section{Figure 1: Blending method}

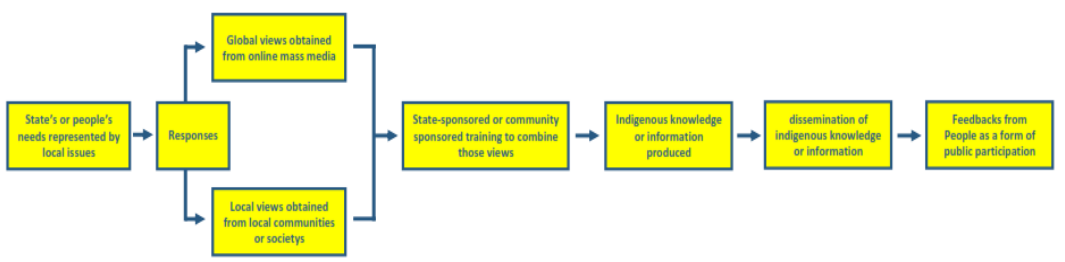

First, the interests or needs of the people of sub-Saharan countries will be represented by various local issues such as politics, education and other issues. The issues will get a response comes from two sources, bottom-up local community that represent interests and top-down approach that represent the sources that contains various things to meet the interests or needs of the people of sub-Saharan countries represented by local issues. The solution that is produced through the combination of local and global views is an indigenous 
matter, therefore authors addresses it as indigenous knowledge or information that serves as a solution to the community issues of sub-Saharan states. After obtaining a response from both sources, the next step is to conduct training that can be sponsored by the state or local communities with the aim to create a combination of two sources; local communities and global issues. It is important to create a comprehensive and effective solution, since it is a combination of a bottom-up approach and a top-down approach. Indigenous knowledge or information is disseminated through radio for people in sub-Saharan countries in the form of oral information in languages recognized by the people of sub-Saharan countries, both in urban communities and in rural areas. Finally, the information will receive feedback from the community as a form of participatory community. Authors expect that there will be quality development as well as the educational experience gained by the community, especially rural communities. In addition to this, the author also has expectations for countries to develop a variety of bottom-up community development methods so that empowerment society in their country becomes more intensive.

\section{Conclusion}

The modernism paradigm that often adopts a top-down approach model that is considered the most appropriate paradigm to provide solutions to the problem of society empowerment in the community of sub-Saharan countries, especially rural communities is inappropriate, because empirically it does not contribute to the society empowerement of sub-Saharan countries. This failure is caused by a misunderstanding of the modernism paradigm in terms of community's condition of sub-Saharan countries, especially those who are in conditions that are less developed than the urban communities. Therefore, the author launched a bottom-up empowerment society method using the marginal paradigm of utilitarianism through the use of radio to disseminate indigenous knowledge or information supported by some empirical data about the conditions of the people of African states. Blending method of online news sites and the interests of the community are implicated through indigenous knowledge required. The first step of the method is to emphasized interests of the people in sub-Saharan countries that is represented by various issues, such as political issues, education and other issues. Then, the issues will get a response that comes from two sources; local and global communities. After obtaining a response from both 
sources, the next step is to conduct training that can be sponsored by the state or local communities as a form of community development, to create combination of two sources. The thing or solution that is produced through a combination of views from the local community that comes from the global community is indigenous matter, so the author call it as 'indigenous knowledge or information' as a solution of community issues. After that, indigenous knowledge or information is disseminated through radio to the people of sub-Saharan countries in the form of oral information in the language recognized by the people of sub-countries, both in urban communities and in rural communities. Finally, it will receive feedback from the community as a form of participatory community in sub-Saharan countries towards knowledge process making matters relating to local issues in sub-Saharan countries. The author's expectation of the conditions arise due to the application of the method to increase the commu-nities' quality of life, especially rural communities, which are in sub-Saharan countries. 


\section{References}

\section{Books}

Effendy, O. 1992. Dinamika Komunikasi. Bandung: Remaja Rosdakarya.

Hicks, S., E. Halpin and E. Hoskins. 2000. Human Rights and the Internet. London: Macmillan.

James, J. 2005. Technological blending in the age of the internet: A developing country perspective. Telecommunications Policy.

Mansell, R. and U. When. 1998. Knowledge Societies: Information Technology for Sustainable Development. Oxford: Oxford University Press.

Manzo, K. 1995. "Black consciousness and the quest for a countermodernist development”. In: Crush J (ed.) Power of Development. London: Routledge.

Michiels, S. and L. Van Crowder. 2001. Discovering the 'Magic Box': Local Appropriation of Information Communication Technologies (ICTs). Rome: FAO.

Moore, D. B. and GJ Schmitz. 1995. Debating Development Discourse: Institutional and Popular Perspectives. New York: St Martin's Press.

Ogan, C., Bashir M., and Camaj L. 2009. Development communication: The state of research in an era of ICTs and globalization. International Communication Gazette.

Rakhmat, J. 1998. Catatan Kang Jalal: Visi media, politik, dan pendidikan. Bandung: Remaja Rosdakarya.

Parpart J. 1995. "Deconstructing the development expert: Gender, development and the vulnerable groups". In: Marchand M and Parpart J (eds) Feminism Postmodernism Development. New York: Routledge.

\section{Journal Article}

Ilboudo, J. P. and R. del Castello .2003. "Linking rural radio to new 
ICTs in Africa: Bridging the rural digital divide”. In: Girard B (ed.) The One to Watch: Radio, New ICTs and Interactivity. Rome: FAO.

Knight R. 1995. Knowledge-based development: Policy and planning implications for cities. Journal of Urban Studies.

Milan, S. 2009. Four steps to society media as a development tool. Development in Practice. 